\title{
Eastern-European Transnational Families as Agents of Social Change: Discursive Facets of Gender, Migration, and Childhood as Constructed Reality
}

\author{
Viorela Ducu and Áron Telegdi-Csetri: Managing "Difference" \\ in Eastern-European Transnational Families
}

Frankfurt am Main: PL Academic Research-Peter Lang GmbH, 2016

\author{
Cristina Tîrhaș \\ Avram Iancu University, Cluj-Napoca, Romania \\ cristinatirhas@gmail.com
}

The edition of an interdisciplinary volume centered on actual subjects and written by senior and assistant researchers from disciplines such as sociology, anthropology, social work, political philosophy, gender studies, criminology, and international human rights is always welcome. On the global context, a series of contemporary phenomena generated by the constitution and spread of transnational families is taking place and is generating various political, economic, and psycho-social effects on macro-, mezzo-, and micro-social levels. Transnational families are representing what we call social change and, on the other hand, such families are generating various social changes, i.e. relevant transformations which affect the structure and function of the social organization of groups and communities in the medium or in the long term (Boudon 1982/2006).

Even if statistical data and surveys provide a relatively clear image on the state and evolution of transnational families and adjacent phenomena, we can hardly affirm that the complexity of this particular social organization can be revealed solely on the basis of quantitative data and statistical analyses. Thus, the quantitative picture can be well completed by more nuanced and deeper qualitative analyses. The present volume can be integrated in the line of these latter qualitative approaches. Edited by Viorela Ducu and Áron Telegdi-Csetri, the volume titled “Managing 'Difference' in Eastern-European Transnational Families" is the result of a series of conjugated efforts made by the authors within the context of a research grant supported by the Romanian National Authority 
for Scientific Research and Innovation and hosted by the Centre for Population Studies, Babeş-Bolyai University in Cluj-Napoca. Consequently, the volume has an empirical coherence, and its objectives are well contoured right from the beginning so that we can read a qualitative treaty on various facets of the contemporary European transnational family.

The case of the transnational family is approached through some pressing problems which are currently setting the agenda both for public authorities and social research. Thus, themes like external migration and its adjacent phenomena (i.e. adaptation, integration, discrimination, segregation, assimilation, return migration, human/citizen/worker rights, and especially children rights), the preservation of identity in the context of socio-cultural differentiation and globalization (i.e. religion, native vs. foreign language, traditions, transnational communication, preserving or developing social capital and social networks), gender role adjustment in transnational contexts (emancipation, egalitarian capital, gender roles, migrants by gender/feminization of migration), transnational criminality (human trafficking, sexual exploitation/prostitution, smuggling), etc. are developed through studies which bring explanatory-theoretical (i.e. analytical) and applicative approaches to the field.

As a process of reflection and individual disposition, change implies the choice of a model, decision-making, and action; the effects of changes are frequently critical for the existing social equilibria. On the individual level, transformations are dependent on the psychosocial context and on the perceptions of those social groups with whom individuals interact; usually, change presupposes the restructuring of the existing social relations and that of socio-cultural environments (Nisbet 1969/1992).

When discussing in the introductory chapter (Transnational DifferenceCosmopolitan Meaning, 13-23) the concept of difference from the title of the volume, its editors, Áron Telegdi-Csetri and Viorela Ducu, show that the studies of the books aimed to identify the "practices of difference, strategies of coping and emancipation, new gender roles and social actors" and, in this sense, the "units of research" are a "feedback for academia" (Id.: 13) in the multi-sensory frontier zone of Eastern Europe, in which a handful of historical and political developments of post-Second World War decades bring "problematically new identities into the bloodstream of an envisaged European society" (Id.: 14). In Europe, there are massive flows of political and post-war emigration from former Yugoslav regions, global economic crisis and West European labor market attraction for Eastern European workforces, followed by political and economic measures to regulate the mass immigration phenomenon and, finally, the Syrian war struggle towards the refugee crisis develops by "raising fences and ending the presumably cosmopolitan politics" of many European countries (Id.: 14). 
The articles of the entire volume indicate that social research on transnationality looks at the "differences" which occurred in the family in the context of globalization. The studies show that Eastern Europe is a space of differences in many aspects: historical appurtenance (East vs. West), religion (Catholic, Orthodox, Protestant, Islamic), unequal economic development, different times of EU and Schengen integration, etc., and all "these differences are translated into variations in the freedom of movement, residence, employment, access to welfare, citizenship facilitation, inter-country adoption, etc." (Id.: 15).

On the level of public opinion and mass media, the traditional family and parenthood are seen in a pessimistic way; social change and untraditional families, cultural diversity, and partially the whole migration phenomenon are seen as factors which determine the weakening of the classic family (such transformations can be labeled as world revolution-Goode 1970). In the contemporary world, we are witnessing forms of experiencing and explorations in order to achieve a new form of familial equilibrium both in terms of marriage and alternative marriage and in the form of parent-child relationship. At the same time, new values, attitudes, and behaviors are emerging in the configurations of familial relations, and-in this contexts-the study of the transnational family is legitimated as an important research subject.

The sections of the volume provide a triangle on the vast analysis of the differences which are manifest in the transnational European family: Transnational Families in a Gendered Perspective; Couples within the Context of Migration; Challenges of Transnationalism towards Childhood.

Constructed from a gendered perspective, the article "Partitioned Paternity: Models of Cross-Border Fathering in Ukrainian Transnational Families" (Alissa Tolstokorova 2016: 27-41) offers a deep view on cross-border paternity and paternal care, identifying several types of "responsible fathering" among Ukrainian migrant men: check-paying fathers (high degree of paternal responsibility), reemerging fathers (moderate degree), and "waning fathers" (low degree). The "male perspective" in transnational family appears as a welcome issue given the fact that Ukrainian men's migration is a wide-spread phenomenon across international mobility of Eastern European citizens pushed away from their countries (and often from their families) by economic factors: males represent over two-thirds of all Ukrainians working abroad, around half of whom have dependent children. The transnational family is seen as a modernized model of family ties due to transnational migration and global network society. The multistaged field research (interviews and focus groups with 43 migrants and their family members, with 23 experts from various domains, and non-participant observation) underlines the rise of the "new fathers" cohort (Cotrane \& Allen 1994—qtd. in Tolstokorova 2016, reviewed volume), "performing their paternity 
roles across borders" (Id.: 36) according to the identified models of paternity already described.

In the chapter "How Family and Emotional Ties Are Used as Coercive Instruments by the Exploiters on the Romanian Feminine Migration. The Study Case of Italy" (pp. 43-62), Rafaela Hilario Pascoal and Adina Nicoleta Erica Schwartz offer a focused (qualitative) understanding of multiple relations between the children left behind and human trafficking, the role of family in human trafficking, and the coercive instrument of motherhood in the exploitation of labor as a criminal practice in Italy. Using a mixed methodology (content analysis, participant observation, and interviews) and collaborating with several associations from Italy and Romania, the authors were able to develop a complex case study in which the picture of exploitation of Romanian female workers (employed in the domestic sector under conditions of low salary and extensive working hours - up to 16 hours per day - as badanti, agriculture laborers in isolation and disrespect, physically and/or emotionally abused, sometimes sexually exploited and harassed or forced into begging) took place. Added to the extreme (economic, social, and psychological) vulnerability of these women, there is the use of children as coercive instruments in exploitation (despite that sexual exploitation in work relations is a less visible phenomenon). Furthermore, as the analysis shows, the migration process of these women has left three generations exposed to human trafficking (the mothers, second generation: the children left behind, and third generation who are perpetuating an absent motherhood role (Id.: 59).

"The Issue of Emancipation in the Case of Romanian Migrant Women" (pp. 63-75) signed by Anca Raluca Aştilean exposes a feministic approach on female emancipation and gender empowerment in the migration context, which is seen as an individual process of gender-role transformation. The qualitative investigation consisting in the collection of data from 40 migrant women (from three Romanian villages, three Romanian towns, London-UK, and Mons-Belgium) covers various themes: "breadwinners", "the responsibility of childcare", "professional emancipation", and "love and home". The results show the many ways in which the migration decision and life as a migrant (couples) can change a woman's life, social status, and perspective from a "culture of male control" to gender equality and female emancipation (Id.: 74).

The next article (Armela Xhaho and Erka Çaro: "Gendered Work-Family Balance in Migration: Albanian Migrants in Greece”, pp. 77-93) follows the same line of gender-related issues in the case of Albanian parents after their migration to Greece. Work-family balance is an issue of challenge especially in the case of migrant working parents and manifests itself at many levels: the gendered negotiation of work and family conflicts, pressure on migrating mothers, ethnicity, lack of social and extended family support, economic struggles of migrant families, and so on. Studying the biographies of 42 Albanian migrants, 
the analysis has pointed out changes in gender power position, extracting diverse models of re-constructing the "hegemonic mothering" life model and "deconstructing gender ideologies of mothering" of Albanian migrant women. "Care gap" (i.e. the double need of economic survival and motherhood) and "double burden" (i.e. reproductive and productive labor) are also analyzed in a qualitative manner. Differences are "mapping out (...) in terms of sacrifices, negotiations and dilemmas of working parents in balancing work and family" ("good worker" and "good parent") and also looking for masculine and feminine roles perpetuated by gendered parenthood care (Id.: 78).

The next three studies placed special focus on couples within the context of migration, shedding light on the main differences through multiple levels of comparison and categories of analysis:

In the chapter titled "Egalitarian Capital Gained in Norway or Brought from Poland? Experiences of Migration and Gender Equality among Polish Couples in Norway" (pp. 97-112), Magdalena Žadkowska and Tomasz Szlendak investigate the family life of Polish couples in Poland (more traditional family attitudes) and Norway (more egalitarian ones), searching for different degrees of "egalitarian capital" (values and practices of researched couples) encouraged by the differences in the social system, work places, labor climate, and social patterns of these two countries.

In "Global Migration and Intermarriage in Chinese-Hungarian Context" (pp. 113-130), Nóra Kovács offers a social-anthropological view on tensions and challenges due to the different socio-cultural backgrounds of a couple formed of a Hungarian woman and a Chinese man who have been together for thirty years: the spouses' representations of marriage, family, and love may serve as a case study in understanding transnationality in intimate relationships and couple life (as mixed marriage). The study also aims at offering a large anthropological picture of "locations, social networks, and discourse and symbol system affecting migrants' lives" (Id.: 118-119), while using literature review and several comprehensive interviews concerning Chinese-Hungarian mixed couples. The data analysis scrutinizes the narrative process and its interpersonal context, indicating the multiple factors involved in these relationships' dynamics (Id.: 120-123).

Viorela Ducu and Iulia Hosu in their chapter "Bi-National Couples with a Romanian Partner in the European Context" (pp. 131-148) are presenting an exploratory approach to understanding the degree of importance of the native country's cultural heritage (religion, language, education, and tradition) among bi-national couples. The research is based on a qualitative analysis of 10 interviews (individuals and couples) with Romanian citizens living in the UK and Belgium. This approach is preceded by the synthesis of statistical data on the international migration of Romanian citizens coming in different waves and their correspondent cohort characteristics. Variables such as country of origin and host 
country, degree of social acceptance, the national or binational practices (language of the families, name and citizenship of the children, religion as differences appear) are taken into account in this qualitative study. As a conceptual novelty, the three strategies of language use in a binational couple proposed by S. Gaspar (2010, qtd. in Ducu \& Hosu 2016, reviewed volume)—assimilation, binationality, and peripatetic-are completed with a fourth option, i.e. neutral (the practice of the use of a third language in the family). The study discusses the evolution of social acceptance of Romanian migrants into the new society (reduction in negative perceptions towards them), the role of pragmatic vs. emotional factors in decision-making processes concerning the family, and the sensitive issue of raising and educating the children of the binational couples in a (new) foreign country.

In connection with the above mentioned themes and chapters, we can enter into a discussion on transnational couples from the perspective of Gary Becker's marriage market theory (1991). This theory, starting from the concept of social exchange, uses the concept of capital (financial, erotic, symbolic, etc.) and refers to marriage as a form of capital exchange, a form of socio-cultural process of permanent selection. The factors which enable the process of selection (physical proximity, rational choice, cultural, social, and psychological compatibility, etc.) conjugate themselves in such a way that similarities and differences create, after all, a so-called multiple homogamy, especially in terms of values, attitudes, and personality patterns (Hogg \& Cooper 2007). This phenomenon of selection, called also multi-criteria homogamy (Ilut 2005) is salient in the context of contemporary Europe, where homogamy criteria, such as race, ethnicity, or religion, are more nuanced, and the whole process of partner selection and the transformations of the family life become flexible, which then has several consequences on the life of the family (e.g. raising and educating the children in mixed, transnational families-see also Benokraitis 2005).

In terms of such challenges, Georgiana Cristina Rentea and Laura-Elena Rotărescu, in their chapter titled "Yesterday's Children, Today's Youth: the Experiences of Children Left Behind by Romanian Migrant Parents" (pp. 151-170) explore the challenging experiences of those children (from several Romanian villages) who lack the presence of one or both of their parents and the ways in which "the evolution of family relationships, individual and family life plans" (p. 151) take shape in these contexts. The authors try to figure out the involved actors' main strategies of adaptation and coping with this phenomenon of absent parents. A series of literature findings regarding these experiences (e.g. the emergent meaning of concepts and phenomena such as the constitution of gender in migrants' transnational households, the gender of the missing parent, and their effects on children's development) are discussed in this small-scale qualitative study, which surely opens the way to future analytical developments and interpretations. The 
research subjects were seven young people from Romania (19-22 years old), who had migrant parents. The results shows that the pivotal reason of the parents' migration in order to work abroad, accompanied by leaving their children at home, is the financial constraints of their family and that the young subjects are aware of their parents' sacrifice and forthcoming material advantages. The subjects are aware of the negative emotional and social implications (feelings of loneliness, neglect and abandonment, lower level of interest in school performance, poor relationships with the family members remained at home, etc.) of their decisions. Indeed, the time right after leaving and the many years after the parent's absence (especially when the absent parent was the mother, despite the compensatory role of technological communication between parent and child) are recalled as a sacrifice. Among the perceived advantages of this life strategy, we can mention: higher income, better living conditions, family welfare, money spent on the children's education, school results, financial independence, and good job prospects. The future life plans of the young interviewed tend to be oriented towards good education at home in order to obtain a good (well-paid) job in Romania.

Bojan Petrovic in his essay "Intercountry Adoption: Human Rights Perspective" (pp. 171-185) casts light on the tensions between the legal framework of intercountry adoption and the particular contexts (legal, sociological, and psychological) on which the formal rules should be applied. Regarding the contexts where intercountry adoptions are prohibited by law, Bojan Petrovic concludes that "Intercountry adoption should be partly solving the problem (...) providing an opportunity for children to grow up in a family" and "the international community has a positive obligation (...) to take steps to raise awareness in every state of the status and position of these children (...) institution of adoption should have the unconditional support" (Id.: 183).

The nuanced way of analyzing the information coming from various sources through various methods (interviews, observation) is ensured by the qualitative research design so that the readers get access to a shared, constructed reality. Due to their contextual and expressive nature, qualitative studies have the value of transgressing real or projected social spaces as they are (re)presented in the subjects' minds and memories. Thus, such studies can offer a perspective in connection with the ways in which subjects experience reality (first-hand perspective-see also Liamputtong 2008). Obviously, besides the qualitative approach, the values of the volume "Managing Difference in Eastern-European Transnational Families" is given also by the mentioning of the quantitative background of the researched phenomena, and such framework facilitates openness and comparison. From here, I assume, it is only one step towards more advanced transdisciplinary, multimethod approaches and, finally, towards applicative, policy-centered research. 


\section{References}

Becker, Gary. 1991. A Treatise on the Family. Cambridge: Harvard University Press. Benokraitis, Nijole V. 2005. Marriages and Families. New Jersey: Pearson Education. Boudon, Raymond (ed.). 1982/2006. Tratat de Sociologie. Bucharest: Editura Humanitas.

Goode, William. 1970. World Revolution and Family Pattern. New York: Free Press. Hogg, Michael A., Cooper, Joel. 2007. The Sage Handbook of Social Psychology. London: SAGE Publications.

Iluț, Petru. 2005. Sociopsihologia şi antropologia familiei. Iaşi: Polirom.

Liamputtong, Pranee (ed.). 2008. Doing Cross-Cultural Research. Ethical and Methodological Perspectives. Dordrecht: Springer.

Nisbet, Robert. 1969/1992. Social Change and History: Aspects of the Western Theory of Development. Oxford: Oxford University Press. 